Syntax Literate: Jurnal Ilmiah Indonesia p-ISSN: 2541-0849

e-ISSN : 2548-1398

Vol. 6, No. 7, Juli 2021

\title{
STUDI TENTANG LOYALITAS NASABAH DANA DI PT BANK BNI SYARIAH CABANG PEKALONGAN
}

\section{Mohamad Zuaim Rusydi}

Universitas Diponegoro (UNDIP) Semarang Jawa Tengah, Indonesia

Email: mohamadzuaimrusydi@students.undip.ac.id

\begin{abstract}
Abstrak
PT Bank BNI Syariah Kantor Cabang Pekalongan memiliki cakupan wilayah operasional yang meliputi wilayah Kota Pekalongan, Kabupaten Pekalongan, Kabupaten Tegal, Kota Tegal, Kabupaten Brebes, Kabupaten Batang, dan Kabupaten Pemalang. Data tahun 2000 hingga 2011 menunjukkan terjadinya perlambatan ekspansi dalam peningkatan Dana Pihak Ketiga (DPK) dibandingkan dengan pergerakan pada periode 6 tahun terakhir sejak tahun 2012 sampai tahun 2018. Gambaran stagnansi ini menunjukkan bahwa masih terdapat hal-hal yang belum dioptimalkan dalam melakukan pengelolaan dan maintenance nasabah dana, meskipun layanan yang diberikan oleh setiap pegawai khususnya sales telah sesuai dengan Standar Operasional Prosedur (SOP) perusahaan. Penelitian ini bertujuan untuk menganalisis pengaruh personal attitude bankers dan persepsi manfaat terhadap kepuasan dan loyalitas nasabah. Metode penelitian ini menggunakan pendekatan penelitian kuantitatif dan analisis data menggunakan SEM (Structural Equation Model) dengan software AMOS. Hasil penelitian ini menunjukkan bahwa personal attitude bankers dan persepsi manfaat berpengaruh terhadap kepuasan dan loyalitas nasabah.
\end{abstract}

Kata Kunci: sikap pribadi bankir; persepsi manfaat; kepuasan nasabah; loyalitas nasabah

\section{Abstract}

PT Bank BNI Syariah Pekalongan Branch Office has an operational area that is the area of Pekalongan, Pekalongan Regency, Tegal Regency, Tegal City, Brebes Regency, Batang Regency, and Pemalang Regency. Data from 2000 to 20111 shows the historical expansion in the expansion of third-party funds (DPK) in divided by means in the last 6 years period from 2012 to 2018. This stagnant image indexes this, there are still things that have not beentomed in the management and maintenance of funds, although the services by each employee, especially sales in accordance with the operational standards of the company's procedures (SOP). This research became a verb for the influence of the influence of personal attitudes of bankers and the benefits of perception on the financial and customers who are still alive. This research method uses quantitative data research and analysis using SEM (Structural Equation Model) with AMOS software. The results of this study

$\begin{array}{ll}\text { How to cite: } & \text { Rusydi, Mohamad Zuaim (2021) Studi Tentang Loyalitas Nasabah Dana di PT Bank BNI Syariah } \\ & \text { Cabang Pekalongan. Syntax Literate: Jurnal Ilmiah Indonesia. 6(7). http://dx.doi.org/10.36418/ } \\ & \text { syntax-literate.v6i7.2484 } \\ & \text { 2548-1398 } \\ \text { E-ISSN: } & \text { Ridwan Institute }\end{array}$

Published by: Ridwan Institute 
showed, the personal attitude of bankers and the perception of benefits to customers and customers.

Keywords: personal attitude bankers; persepsi manfaat; customer satisfaction; customer loyalty

\section{Pendahuluan}

Bank syariah merupakan lembaga jasa keuangan yang mengadopsi hukum syariah Islam dalam kegiatan usahanya. Kegiatan perbankan syariah termasuk mengumpulkan dana nasabah, menyalurkan dana dalam bentuk pembiayaan, dan menawarkan produkproduk jasa keuangan (Zaini, 2015).

Kualitas layanan merupakan faktor terpenting bagi perbankan syariah untuk menghadapi persaingan yang ketat dalam era globalisasi (Al Arif, 2021). Pemberian pelayanan yang optimal, maka nasabah akan puas dengan kinerja perbankan syariah tersebut dan kemudian akan menjadi nasabah loyal. Selain itu, apabila nasabah puas dengan suatu layanan perbankan syariah, pada umumnya nasabah akan merekomendasikan perbankan syariah tersebut kepada keluarga, teman, maupun kolegannya.

PT Bank BNI Syariah merupakan salah satu perbankan syariah di Indonesia. BNI Syariah cabang Pekalongan merupakan salah satu kantor cabang yang pertama kali didirikan oleh PT Bank BNI Syariah yang mencakup wilayah Kota Pekalongan, Kabupaten Pekalongan, Kabupaten Tegal, Kota Tegal, Kabupaten Brebes, Kabupaten Batang, dan Kabupaten Pemalang. Luasnya cakupan wilayah operasional ini menjadikan Bank BNI Syariah Pekalongan memiliki baseline nasabah dana maupun pembiayaan yang sangat signifikan.

Data tahun 2000 hingga 2011 menunjukkan terjadinya perlambatan ekspansi dalam peningkatan Dana Pihak Ketiga (DPK) dibandingkan dengan pergerakan pada periode 6 tahun terakhir sejak tahun 2012 sampai tahun 2018. Posisi DPK tahun 2012 hingga tahun 2018 mengalami peningkatan yang sangat signifikan dari posisi terakhir bulan Desember 2011 sebesar Rp. 86,7 Milyar ke posisi Rp. 460 Milyar pada akhir bulan Desember 2018.

Gambaran stagnansi pergerakan DPK BNI Syariah Pekalongan pada tahun 2007 sampai 2011 dibandingkan dengan tahun 2012 sampai dengan tahun 2018 menunjukkan bahwa masih terdapat hal-hal yang belum dioptimalkan dalam melakukan pengelolaan dan maintenance nasabah dana, meskipun layanan yang diberikan oleh setiap pegawai khususnya sales telah sesuai dengan Standar Operasional Prosedur (SOP) perusahaan.

Hasil pra penelitian yang dilakukan oleh peneliti kepada 10 orang responden di BNI Syariah Pekalongan ditemukan bahwa sebanyak 6 orang responden menyimpan dananya di Bank BNI Syariah Pekalongan karena menaruh kepercayaan yang besar pada salah satu sales funding BNI Syariah Pekalongan. Keenam responden memberikan kepercayaan yang besar kepada salah satu sales funding karena sales funding tersebut memiliki personality yang baik dan konsisten. Hal ini membuat nasabah merasa 
semakin nyaman dengan pegawai tersebut dan secara sukarela menjadi nasabah dana yang loyal. Alasan berbeda dikemukakan oleh keempat responden sisanya. Keempat orang responden yang tersisa memilih menyimpan dananya di Bank BNI Syariah Pekalongan karena faktor persepsi manfaat seperti lebih aman menyimpan dananya di bank dibandingkan di rumah, ATM BNI tersebar di berbagai lokasi yang mudah dijangkau, dan adanya e-channel semakin mempermudah transaksi keuangan nasabah.

Etika memiliki makna nilai moral seseorang atau sekelompok orang yang membimbing perilakunya untuk berbuat baik dan benar (Jufrizen, 2016). Etika bankir sangat diperlukan karena dapat menumbuhkan rasa percaya diri, disegani rekan kerja dan nasabah, serta dapat menarik calon nasabah.

Kepuasan customer (nasabah) menurut Kotler dan Keller merupakan suatu luapan perasaan senang maupun kecewa yang dirasakan oleh nasabah setelah membandingkan produk yang diterima dengan apa yang diharapkan (Ishak \& Azzahroh, 2017). Etika karyawan bank (personal attitude bankers) diperlukan untuk membangun kualitas SDM pegawai perbankan. Perusahaan dapat berjalan dengan baik apabila pegawai dapat memberikan kualitas pelayanan optimal sehingga berdampak pada tercapainya target perusahaan.

Oliver mendefinisikan loyalitas sebagai keinginan kuat bagi nasabah dalam pembelian suatu produk atau layanan secara berulangkali dan tidak akan berpindah ke perusahaan lain (Ishak \& Azzahroh, 2017). Penelitian (Porral \& Lang, 2015) membuktikan bahwa loyalitas pelanggan pada suatu produk akan meningkatkan minat pelanggan tersebut dalam hal pembelian produk atau jasa kembali dikemudian hari. Oleh sebab itu loyalitas pelanggan secara tidak langsung akan meningkatkan daya saing perusahaan (Lee \& Lee, 2013).

Eksistensi perusahaan dapat dipertahankan melalui strategi penerapan etika karyawan (personal attitude bankers) dan peningkatan kualitas pelayanan. Dengan adanya penerapan kedua strategi ini maka kesempurnaan etika pelayanan dapat terwujud. Penerapan standar etika karyawan (personal attitude bankers) bertujuan untuk membuat nasabah puas dan pada akhirnya akan menumbuhkan loyalitas (Wakkee \& Sleebos, 2015).

Perkembangan teknologi dan informasi saat ini berkontribusi besar pada dunia perbankan. Dengan adanya perkembangan teknologi, nasabah menjadi merasa lebih mudah, praktis, dan efisien waktu untuk mendapatkan pelayanan dari bank. Persepsi manfaat didefinisikan sebagai suatu ukuran yang mempercayai bahwa pengguna akan memperoleh manfaat dari teknologi yang digunakan. Indikator-indikator kemanfaatan penggunaan sistem informasi menurut Davis F.D antara lain makes job easier (membuat lebih mudah), usefull (berguna), increase productivity (menambah produktivitas), enchance effectiveness (mempertinggi efektifitas), dan improve job performance (mengembangkan kinerja pekerjaan) (Hardi, Wahyudi, \& Djastuti, 2016).

Persepsi kemudahan dapat ditinjau dari tingkat kepercayaan pengguna teknologi BNI Syariah dimana teknologi yang digunakan mudah diaplikasikan, mudah ditelaah (dipahami), efisien waktu dan biaya. Adanya ketertarikan nasabah untuk selalu 
bertransaksi menggunakan teknologi BNI Syariah (intention to use) dan ditambah dengan pertimbangan faktor keuntungan dan kemudahan dalam penggunaan, maka berefek dapat meningkatkan loyalitas nasabah Bank BNI Syariah (Husna, 2021).

Indikator utama loyalitas nasabah adalah kepuasan dari seorang nasabah. Kepuasan terhadap pelayanan yang diberikan akan membuat nasabah loyal dan menarik minat calon nasabah baru. Hal ini juga memungkinkan nasabah tersebut menjadi semakin loyal dalam jangka waktu yang lama (Artanti \& Ningsih, 2011).

Berdasarkan (Ishak \& Azzahroh, 2017) melakukan penelitian terhadap pengaruh akan kualitas pelayanan terhadap loyalitas nasabah di bank syariahm dengan variabel intervensinya adalah kepuasan nasabah. Hasil penelitian menemukan adanya hubungan loyalitas pelanggan dipengaruhi oleh kepuasan pelanggan. Faktor kepuasan nasabah mempunyai dampak langsung pada penggunaan produk dan jasa dari suatu bank secara intens dan tidak berkeinginan untuk beralih ke bank lain. Konsekuensi perilaku pelanggan yang puas akan membentuk loyalitas. Penelitian ini bertujuan untuk menganalisis pengaruh personal attitude bankers dan persepsi manfaat terhadap kepuasan dan loyalitas nasabah.

\section{Metode Penelitian}

Metode penelitian ini menggunakan pendekatan penelitian kuantitatif untuk mengungkap pengaruh variabel personal attitude bankers dan persepsi manfaat terhadap kepuasan dan loyalitas nasabah kantor Cabang BNI Syariah Pekalongan.

Sumber data primer didapatkan melalui hasil kuesioner nasabah dana Bank BNI syariah Kantor Cabang Pekalongan yang berjumlah 125 orang. Analisis data pada penelitian ini menggunakan metode SEM-AMOS karena analisis SEM dapat memperhitungkan hubungan seluruh variabel secara simultan atau bersamaan, menganalisis faktor, jalur, dan regresi, dan mampu mengkonfirmasi teori sesuai data penelitian.

\section{Hasil dan Pembahasan}

1. Uji Validitas

Kuesioner harus diuji lebih dulu sebelum dibagikan kepada segenap responden penelitian. Tes kuesioner memiliki maksud untuk mengetahui apakah kuesioner layak atau tidak untuk dipakai sebagai instrumen penelitian. Kuesioner diuji menggunakan uji validitas dan reliabilitas (Yusup, 2018). Kriteria pengambilan keputusan uji validitas didasarkan pada hasil perbandingan nilai Corrected ItemTotal Correlation dengan nilai $r$ tabel $(n=125$ pada taraf signifikansi 0,05$)$ yaitu 0,175 . Jika hasil perbandingan menunjukkan nilai yang lebih besar dari nilai $r$ tabel, maka indikator tersebut akan dianggap valid. 
Tabel 1

Hasil Pengujian Validitas Instrumen

No Pertanyaan

HASIL

\section{Personal Attitude Bankers}

1. Pegawai bersikap sopan dan ramah saat melayani nasabah

VALID

2. Pegawai berpenampilan rapi dan menggunakan name tag (tanda pengenal) VALID

3. Pegawai memakai pakaian yang pantas dilihat VALID

4. Pegawai berbicara dengan menggunakan bahasa dan tutur kata yang baik kepada VALID nasabah

5. Pegawai dapat mengerti dan memberikan solusi atas masalah maupun VALID pertanyaan nasabah

6. Pegawai menunjukkan ekspresi yang ceria dan menyenangkan saat melayani VALID nasabah

\section{Persepsi Manfaat}

7. Lokasi kantor Bank BNI Syariah mudah dijangkau dan letaknya strategis $\quad$ VALID

8. Produk dan jasa yang ditawarkan oleh Bank BNI Syariah mampu memenuhi $\quad$ VALID kebutuhan nasabah

9. Produk dan jasa yang ditawarkan oleh Bank BNI Syariah dapat meningkatkan VALID produktivitas lalu lintas transaksi keuangan nasabah

10. Teknologi Bank BNI Syariah mudah dipahami dan digunakan sehingga efektif VALID dalam menghemat waktu nasabah

11. Teknologi dan produk / jasa Bank BNI Syariah efektif dalam meningkatkan VALID kinerja pekerjaan yang berkaitan dengan transaksi keuangan

\section{Kepuasan Nasabah}

12. Nasabah merasa puas setelah menggunakan produk dan jasa yang telah diterima VALID

13. Biaya administrasi sudah sesuai dengan harapan nasabah (admin fee) $\quad$ VALID

14. Produk dan jasa yang telah diterima sesuai dengan kebutuhan nasabah VALID

Loyalitas Nasabah

15. Saya akan teratur menambah jumlah saldo tabungan saya di Bank BNI Syariah VALID

16. Saya akan menggunakan berbagai macam produk atau jasa yang ditawarkan VALID oleh Bank BNI Syariah

17. Saya hanya akan bertransaksi dengan menggunakan Bank BNI Syariah VALID

18. Saya tidak terpengaruh oleh bujukan bank lain $\quad$ VALID

19. Saya akan menginformasikan kepada orang lain bahwa pelayanan Bank BNI VALID Syariah baik dan memuaskan

20. Saya berminat untuk memberikan kritik dan saran kepada Bank BNI Syariah VALID sebagai upaya perbaikan

\section{Uji Reliabilitas}

Proses uji reliabilitas untuk mengetahui tingkat keakuratan (akurasi) data penelitian. Pengujian ini membandingkan nilai koefisien alpha dengan nilai 0,60. Jika konstruk atau variabel menunjukkan nilai alpha lebih besar dari 0,60 dinyatakan reliabel (Koestanto \& Yuniati, 2014). 
Tabel 2

Uji Reliabilitas Variabel

\begin{tabular}{llcc}
\hline No. & Variabel & $\begin{array}{c}\text { Alpha } \\
\text { Cronbrach }\end{array}$ & Kesimpulan \\
\hline $\mathbf{1}$ & $\begin{array}{l}\text { Personal Attitude } \\
\text { Bankers }\end{array}$ & 0,884 & Reliabel \\
\hline $\mathbf{2}$ & Persepsi Manfaat & 0,953 & Reliabel \\
\hline $\mathbf{3}$ & Kepuasan Nasabah & 0,969 & Reliabel \\
\hline $\mathbf{4}$ & Loyalitas Nasabah & 0,992 & Reliabel \\
\hline
\end{tabular}

Tabel 2 menunjukkan bahwa keseluruhan variabel memiliki nilai cronbach alpha lebih dari 0,7 sehingga dikatakan bahwa keseluruhan variabel layak untuk digunakan sebagai variabel (konstruk) suatu penelitian.

3. Analisis SEM

a. Pengembangan Model Teoritis

Tujuan penggunaan model tersebut adalah untuk memberikan jawaban atas permasalahan penelitian dan guna tercapainya tujuan penelitian. Konstruk yang mempengaruhi model penelitian ini terdiri atas 4 variabel pembentuk model dan 20 indikator pembentuk konstruk.

b. Menyusun Diagram Alur (Path Diagram)

Pembentukan diagram alur (path diagram) dilakukan atas dasar pengembangan model penelitian tinjauan teori. Diagram alur yang ada dapat dipakai untuk proses estimasi menggunakan AMOS.

c. Persamaan Struktural dan Model Pengukuran

Tahapan selanjutnya setelah menyusun diagram alur adalah mengubahnya menjadi persamaan struktural dan persamaan spesifikasi model pengukuran.

d. Memilih Matriks Input dan Teknik Estimasi

Matrik kovarians dipakai sebagai matriks input dalam pengujian Structural Equation Model (SEM). Matriks kovarians dipilih sebagai matriks input karena penelitian yang tengah dilakukan ini bertujuan untuk menguji hubungan kausalitas (Arisena, 2016). Teknik estimasi pada penelitian ini menggunakan maximum likelihood estimation method.

1) Analisis Faktor Konfirmatori Eksogen

Analisis faktor konfirmatori eksogen digunakan untuk menguji undimensionalitas dimensi yang mempengaruhi variabel laten atau konstruk laten pada penelitian ini, yaitu personal attitude bankers dan persepsi manfaat. Hasil analisis faktor konfirmatori eksogen disajikan pada gambar di bawah ini: 

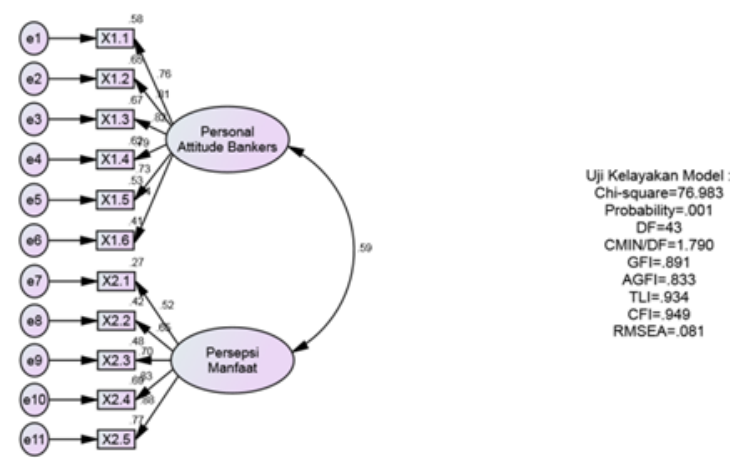

Gambar 1

Hasil Analisis Faktor Konfirmatori Eksogen

Sesuai hasil analisis di atas, dapat dilihat bahwa model ini sudah layak untuk diuji pada tahap full model. Hasil perhitungan chi-square pada konstruk eksogen menunjukkan nilai 76,983. Nilai ini masih diatas nilai chi-square tabel dengan tingkat derajat kebebasan 43 pada tingkat signifikansi 5\% sebesar 59,3. Nilai probabilitas yang didapatkan sebesar 0,001 . Nilai probabilitas ini bernilai lebih kecil dari 0,05. Nilai CMIN/DF yang diperoleh sebesar 1,790, nilai ini bernilai lebih kecil dari 2,00, sehingga masuk kategori fit. Nilai GFI yang didapatkan sebesar 0,891 dan AGFI sebesar 0,833, kedua nilai ini masih berada dalam rentang nilai marginal fit $(0,90)$. Nilai TLI yang diperoleh sebesar 0,934 , nilai ini masih berada dalam rentang nilai marginal fit. Nilai CFI yang didapatkan adalah sebesar 0,949 , nilai ini masih berada dalam rentang nilai marginal fit. Nilai RMSEA yang didapatkan dari hasil pengujian adalah sebesar 0,081, nilai ini lebih kecil dari 0,08, sehingga masuk dalam kategori fit. Hasil pengujian tersebut menunjukkan bahwa konstruk dikatakan telah memenuhi kriteria model fit (Goodness of Fit Indices) karena enam dari delapan syarat kriteria model fit telah memenuhi kriteria model fit. Selain itu, model sudah layak untuk diuji pada tahap full model karena seluruh indikator (observed) memiliki nilai loading faktor lebih dari 0,5.

Uji t terhadap regression weights perlu dilakukan untuk mengetahui kuat dan lemahnya dimensi dalam mempengaruhi faktor latennya. Hasil regression weights faktor konfirmatori konstruk eksogen dapat dilihat pada tabel berikut ini:

Tabel 3

Hasil Regression Weights Faktor Konfirmatori Konstruk Eksogen

\begin{tabular}{llrrrrrl}
\hline & & & Estimate & S.E. & C.R. & P & Label \\
\hline X1.5 & $<---$ & X1 & .992 & .145 & 6.823 & $* * *$ & par_1 \\
\hline X1.4 & $<---$ & X1 & 1.019 & .143 & 7.124 & $* * *$ & par_2 \\
\hline X1.3 & $<---$ & X1 & 1.059 & .148 & 7.174 & $* * *$ & par_3 \\
\hline X1.2 & $<---$ & X1 & 1.027 & .146 & 7.014 & $* * *$ & par_4 \\
\hline X2.5 & $<---$ & X2 & 1.000 & & & & \\
\hline X2.4 & $<---$ & X2 & .956 & .083 & 11.571 & $* * *$ & par_5 \\
\hline X2.3 & $<---$ & X2 & .774 & .094 & 8.200 & $* * *$ & par_6 \\
\hline
\end{tabular}




\begin{tabular}{rrrrrrrr}
\hline & & & Estimate & S.E. & C.R. & P & Label \\
\hline X2.2 & $<---$ & X2 & .802 & .108 & 7.393 & $* * *$ & par_7 \\
\hline X2.1 & $<---$ & X2 & .512 & .091 & 5.621 & $* * *$ & par_8 \\
\hline X1.6 & $<---$ & X1 & 1.000 & & & & \\
\hline X1.1 & $<---$ & X1 & 1.071 & .156 & 6.870 & $* * *$ & par_10 \\
\hline
\end{tabular}

Hasil dari pengujian di atas, terlihat bahwa hasil yang ditampilkan oleh setiap indikator pembentuk variabel laten telah memenuhi kriteria. Hal tersebut dibuktikan dengan nilai Critical Ratio $(\mathrm{CR}) \geq 1,96$ dan probabilitas $<0,05$. Hasil ini menunjukkan bahwa indikator pembentuk variabel laten menggambarkan undimensionalitas. Hipotesis penelitian dikatakan diterima apabila hasil pengolahan data dapat memenuhi syarat tersebut.

2) Analisis Faktor Konfirmatori Endogen

Analisis faktor konfirmatori endogen digunakan sebagai alat uji unidimensionalitas dari dimensi yang mempengaruhi variabel laten atau konstruk laten dalam penelitian ini, yaitu kepuasan nasabah dan loyalitas nasabah (Fahmi, Yozza, \& Hg, 2016). Hasil analisis faktor konfirmatori endogen disajikan pada gambar di bawah ini:

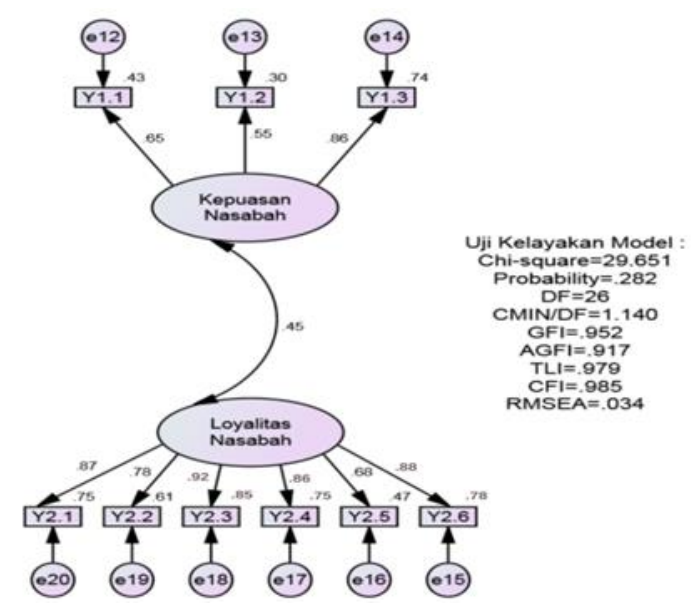

Gambar 2

\section{Hasil Analisis Faktor Konfirmatori Eksogen}

Berdasarkan Gambar 2, diketahui bahwasanya model sudah layak untuk dilakukan pengujian pada tahapan full model. Nilai chi-square pada konstruk endogen yang diperoleh dari hasil perhitungan adalah sebesar 29,651. Nilai ini lebih kecil dari nilai chi-square tabel pada derajat kebebasan 26 dan taraf signifikansi $5 \%$ yaitu sebesar 38,89. Nilai probabilitas hasil perhitungan adalah sebesar 0,282. Nilai probabilitas ini bernilai lebih besar dari 0,05. Nilai CMIN/DF yang diperoleh adalah sebesar 1,140 , nilai ini lebih kecil daripada 2,00. Nilai GFI yang didapatkan adalah sebesar 0,952, nilai ini lebih besar daripada 0,90. Nilai AGFI hasil pengujian adalah sebesar 0,917, nilai ini lebih besar daripada 0,90 . Nilai TLI yang didapatkan sebesar 0,979 , nilai ini lebih 
besar daripada 0,95. Nilai CFI yang diperoleh sebesar 0,985 , nilai ini lebih besar daripada 0,95 . Nilai RMSEA yang didapatkan adalah sebesar 0,034 , nilai ini lebih kecil daripada 0,08 . Keseluruhan hasil pengujian ini menggambarkan bahwa konstruk telah memenuhi kriteria model fit.

Analisis uji t terhadap regression weights diperlukan untuk mengetahui seberapa kuat dimensi-dimensi dapat mempengaruhi faktor latennya. Hasil regression weights faktor konfirmatori konstruk endogen dapat dilihat pada tabel di bawah ini:

\section{Tabel 4}

Hasil Regression Weights Faktor Konfirmatori Konstruk Endogen

\begin{tabular}{rrrrrrr}
\hline Y1.1 & $<---$ & Y1 & 1.000 & & & \\
\hline Y1.2 & $<---$ & Y1 & 1.202 & .242 & 4.965 & $* * *$ \\
\hline Y1.3 & $<---$ & Y1 & 1.417 & .255 & 5.549 & $* * *$ \\
\hline Y2.5 & $<---$ & Y2 & 2.650 & 1.035 & 2.560 & .010 \\
\hline Y2.4 & $<---$ & Y2 & 1.027 & .146 & 7.014 & $* * *$ \\
\hline Y2.3 & $<---$ & Y2 & 4.230 & 1.665 & 2.541 & .011 \\
\hline Y2.2 & $<---$ & Y2 & 3.987 & 1.529 & 2.608 & .009 \\
\hline Y2.6 & $<---$ & Y2 & 1.000 & & & \\
\hline Y2.1 & $<---$ & Y2 & 4.230 & 1.665 & 2.541 & .011 \\
\hline
\end{tabular}

Hasil pengujian menunjukkan bahwa masing-masing indikator yang membentuk variabel laten telah memenuhi kriteria. Hal tersebut dibuktikan dengan nilai Critical Ratio $(\mathrm{CR}) \geq 1,96$ dan probabilitas bernilai kurang dari 0,05 . Hasil ini menggambarkan keseluruhan indikator pembentuk variabel laten mengalami unidimensionalitas. Hipotesis penelitian dikatakan diterima apabila hasil pengolahan data telah memenuhi persyaratan tersebut.

3) Analisis Structural Equation Modelling

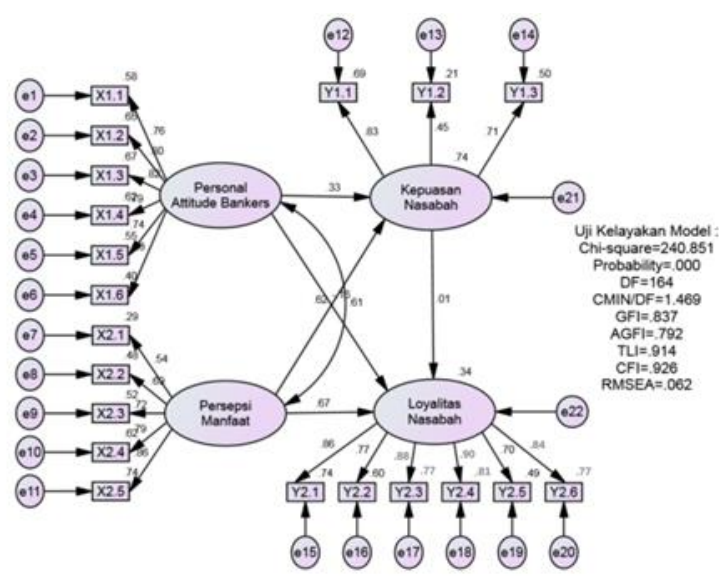

Gambar 3

Hasil Uji Structural Equation Model 
Hasil pengujian di atas, dapat diketahui bahwa model sudah memenuhi kriteria fit. Hal ini dibuktikan dengan telah terpenuhinya tujuh dari delapan syarat kriteria layak full model. Nilai chi-square diperoleh hasil perhitungan yaitu sebesar 240,851. Nilai ini lebih besar daripada nilai chi-square tabel pada derajat kebebasan 164 dengan taraf signifikansi 5\% yaitu 194,8. Nilai probabilitas hasil perhitungan yang didapatkan adalah sebesar 0,000 . Nilai probabilitas hasil perhitungan ini lebih kecil daripada 0,05. Nilai CMIN/DF yang diperoleh sebesar 1,469, nilai ini lebih kecil dari 2,00. Nilai GFI sebesar 0,837 , dimana masih berada pada marginal fit $(0,90)$. Nilai AGFI yang diperoleh adalah sebesar 0,792 , nilai ini masih berada pada marginal fit $(0,90)$. Nilai TLI yang didapatkan sebesar 0,914 , dimana masih berada pada marginal fit $(0,95)$. Nilai CFI yang diperoleh sebesar 0,926, nilai tersebut lebih dari 0,90 . Nilai RMSEA hasil perhitungan menunjukkan nilai sebesar 0,062, nilai ini lebih kecil dari 0,08. Keseluruhan hasil pengujian tersebut menggambarkan bahwa model ini telah memenuhi untuk kriteria model fit.

\section{Tabel 5}

\section{Hasil Regression Weights Analisis Structural Equation Modeling}

\begin{tabular}{|c|c|c|c|c|c|c|}
\hline & & & Est & S.E. & C.R. & $\mathbf{P}$ \\
\hline Y1 & $<--$ & $\mathrm{X} 1$ & .367 & 132 & 2.781 & .005 \\
\hline Y1 & $<--$ & $\mathrm{X} 2$ & 94 & 02 & 52 & \\
\hline Y2 & $<--$ & $\mathrm{X} 2$ & .269 & 137 & 1.967 & .049 \\
\hline Y2 & $<--$ & Y1 & .928 & 087 & 0.633 & $* * *$ \\
\hline Y2 & $<---$ & $\mathrm{X} 1$ & .819 & .098 & 346 & $* * *$ \\
\hline X1.5 & $<--$ & $\mathrm{X} 1$ & 014 & .147 & 5.881 & $* * *$ \\
\hline X1.4 & $<--$ & $\mathrm{X} 1$ & 1.022 & .144 & 7.092 & $* * *$ \\
\hline X1.3 & $<--$ & $\mathrm{X} 1$ & 1.064 & 149 & 7.158 & $* * *$ \\
\hline X1.2 & $<---$ & $\mathrm{X} 1$ & 1.02 & .147 & 6.985 & $* *$ \\
\hline X2.5 & $<---$ & $\mathrm{X} 2$ & 1.00 & & & \\
\hline X2.4 & $<--$ & $\mathrm{X} 2$ & .928 & .087 & 10.633 & $* * *$ \\
\hline X2.3 & $<---$ & $\mathrm{X} 2$ & .819 & .098 & 8.346 & $* * *$ \\
\hline X2.2 & $<--$ & $\mathrm{X} 2$ & .875 & .115 & 7.603 & $* * *$ \\
\hline X2.1 & $<--$ & $\mathrm{X} 2$ & .540 & .094 & 5.767 & $* * *$ \\
\hline Y1.1 & $<--$ & Y1 & 1.000 & & & \\
\hline Y1.2 & $<---$ & Y1 & .782 & 172 & 4.542 & **** \\
\hline Y1.3 & $<--$ & Y1 & .915 & 125 & 7.344 & $* * *$ \\
\hline Y2.5 & $<---$ & Y2 & 2.625 & .988 & 2.656 & .008 \\
\hline Y2.4 & $<--$ & Y2 & 1.153 & 642 & 5.877 & $* * *$ \\
\hline Y2.3 & $<---$ & Y2 & .712 & .463 & 4.653 & *** \\
\hline Y2.2 & $<---$ & Y2 & 3.832 & 1.427 & 2.686 & .007 \\
\hline X1.6 & $<---$ & $\mathrm{X} 1$ & 1.000 & & & \\
\hline X1.1 & $<---$ & $\mathrm{X} 1$ & 1.072 & . 157 & 6.838 & $* * *$ \\
\hline 2.6 & $<--$ & Y2 & 1.000 & & & \\
\hline Y2.1 & $<--$ & $\mathrm{Y} 2$ & 4.062 & 1530 & & .00 \\
\hline
\end{tabular}

Menurut tabel 5, dapat dilihat bahwa setiap indikator pembentuk variabel laten telah memenuhi kriteria. Hal tersebut dibuktikan dengan nilai CR yang 
lebih besar dari 1,96, nilai probabilitas lebih kecil dari 0,05 serta nilai faktor loading lebih besar dari 0,5. Hasil ini memberi gambaran bahwa indikator membentuk variabel laten secara signifikan merupakan indikator dari faktor laten yang terbentuk. Selanjutnya tabel di atas juga menjelaskan bahwa pertanyaan dinyatakan valid apabila memiliki nilai probabilitas kurang dari 0,05 .

\section{Evaluasi Kriteria Goodness of Fit}

Kesesuaian model diuji berdasarkan kriteria goodness of fit. Hasil pengujian penelitian ini menunjukkan bahwa telah terpenuhinya kriteria indeks pengujian kelayakan dari model yang dikembangkan, sebagaimana tertera pada Gambar 3 (Zaelani, Husain, \& Budiyantara, 2020).

5. Intepretasi Model dan Modifikasi Model

Model yang digunakan sudah masuk dalam syarat kriteria yang disyaratkan, oleh sebab itu maka tidak perlu dilakukan modifikasi model. Model yang digunakan sudah dapat digunakan untuk analisis berikutnya. Selanjutnya adalah menginterpretasikan model tersebut.

Indeks untuk setiap konstruk dapat dilihat dari jumlah varians yang diekstraksi oleh variabel yang diteliti. Nilai extracted tinggi memiliki arti jika indikator tersebut sudah dapat mewakili variabel yang akan diteliti. Nilai ini bisa didapatkan dengan persamaan (Ghozali, 2018).

$$
\text { variance extraced }=\frac{\sum \lambda_{i j}^{2}}{\sum \lambda_{i j}^{2}+\sum \varepsilon_{j}}
$$

Selain perhitungan variance extracted, juga dilakukan perhitungan construct reliability. Pengujian reliabilitas digunakan untuk mengetahui hingga sejauh mana alat ukur mampu menunjukkan hasil yang relatif sama jika pengukuran dilakukan berulang kali pada obyek yang sama. Nilai reliabilitas minimum yang dipersyaratkan adalah sebesar $\geq 0,70$. Rumus pengujian reliabilitas dalam Structural Equation Model (SEM) adalah sebagai berikut:

$$
\text { Construct reliability }=\frac{(\Sigma \text { standard loading })^{2}}{(\Sigma \text { standard loading })^{2}+\Sigma \varepsilon j}
$$

\section{Tabel 6}

\begin{tabular}{|c|c|c|c|}
\hline & Loading & Loading ${ }^{2}$ & Error \\
\hline \multicolumn{4}{|c|}{ Personal Attitude Bankers (X1) } \\
\hline $\mathrm{X} 1.1$ & 1 & 1,000 & 0 \\
\hline $\mathrm{X} 1.2$ & 0,759 & 0,576 & 0,241 \\
\hline $\mathrm{X} 1.3$ & 0,688 & 0,473 & 0,312 \\
\hline $\mathrm{X} 1.4$ & 0,739 & 0,546 & 0,261 \\
\hline $\mathrm{X} 1.5$ & 0,669 & 0,448 & 0,331 \\
\hline X1.6 & 0,762 & 0,581 & 0,238 \\
\hline
\end{tabular}

Uji Reliabilitas dan Variance Extract 
Studi Tentang Loyalitas Nasabah Dana di PT Bank BNI Syariah Cabang Pekalongan

\begin{tabular}{|c|c|c|c|}
\hline & Loading & Loading $^{2}$ & Error \\
\hline $\mathrm{X} 1.7$ & 0,777 & 0,604 & 0,223 \\
\hline Jumlah & 5,394 & 4,227 & 1,606 \\
\hline \multicolumn{4}{|l|}{$\begin{array}{l}(\Sigma \\
\text { Loading })^{2}\end{array}$} \\
\hline Reliabel & 0,9477 & & \\
\hline Var.Ext & $\mathbf{0 , 7 2 4 7}$ & & \\
\hline \multicolumn{4}{|c|}{ Persepsi Manfaat (X2) } \\
\hline $\mathrm{X} 2.5$ & 1 & 1,000 & 0 \\
\hline $\mathrm{X} 2.4$ & 0,951 & 0,904 & 0,049 \\
\hline $\mathrm{X} 2.3$ & 0,733 & 0,537 & 0,267 \\
\hline $\mathrm{X} 2.2$ & 0,692 & 0,479 & 0,308 \\
\hline $\mathrm{X} 2.1$ & 0,578 & 0,334 & 0,422 \\
\hline Jumlah & 3,9540 & 3,255 & 1,046 \\
\hline $\begin{array}{l}(\Sigma \\
\text { Loading }^{2}\end{array}$ & 15,6341 & & \\
\hline Reliabel & 0,9373 & & \\
\hline Var.Ext & 0,7568 & & \\
\hline \multicolumn{4}{|c|}{ Kepuasan Nasabah (Y1) } \\
\hline Y1.1 & 1 & 1,000 & 0 \\
\hline $\mathrm{Y} 1.2$ & 1,019 & 1,038 & $-0,019$ \\
\hline Y1.3 & 1,678 & 2,816 & $-0,678$ \\
\hline Jumlah & 3,6970 & 4,854 & $-0,697$ \\
\hline $\begin{array}{l}(\Sigma \\
\text { Loading })^{2}\end{array}$ & 54,6712 & & \\
\hline Reliabel & $\mathbf{1 , 0 5 3 7}$ & & \\
\hline Var.Ext & 1,1677 & & \\
\hline \multicolumn{4}{|c|}{ Loyalitas Nasabah (Y2) } \\
\hline Y2.6 & 1 & 1,000 & 0 \\
\hline Y2.5 & 1,43 & 2,045 & $-0,43$ \\
\hline Y2.4 & 2,4 & 5,760 & $-1,4$ \\
\hline Y2.3 & 2,606 & 6,791 & $-1,606$ \\
\hline $\mathrm{Y} 2.2$ & 2,039 & 4,158 & $-1,039$ \\
\hline Y2.1 & 1,942 & 3,771 & $-0,942$ \\
\hline Jumlah & 11,4170 & 23,525 & $-5,417$ \\
\hline $\begin{array}{l}(\Sigma \\
\text { Loading }^{2}\end{array}$ & 324,1440 & & \\
\hline Reliabel & 1,0434 & & \\
\hline Var.Ext & 1,2991 & & \\
\hline
\end{tabular}

Hasil perhitungan reliabilitas dan variance extract yang terdapat dalam penelitian ini menunjukkan jika tidak ditemukannya nilai reliabilitas dan variance extract yang bernilai kurang dari batas ketetapan nilai. Hal ini dapat ditarik kesimpulan bahwasanya indikator yang dipergunakan sebagai observed variable untuk variabel laten sudah dapat menjelaskan variabel laten yang dibentuknya. 
6. Uji Hipotesis

\section{Tabel 6}

Hasil Estimasi Output AMOS

\begin{tabular}{|c|c|c|c|c|c|c|}
\hline & & & Est & S.E. & C.R. & $\mathbf{P}$ \\
\hline Y1 & $<---$ & $\mathrm{X} 1$ & .367 & .132 & 2.781 & .005 \\
\hline Y1 & $<--$ & $\mathrm{X} 2$ & .494 & .102 & 4.852 & *** \\
\hline Y2 & $<---$ & $\mathrm{X} 2$ & .269 & .137 & 1.967 & .049 \\
\hline Y2 & $<--$ & Y1 & .928 & .087 & 10.633 & *** \\
\hline Y2 & $<--$ & $\mathrm{X} 1$ & .819 & .098 & 8.346 & *** \\
\hline X1.5 & $<--$ & $\mathrm{X} 1$ & 1.014 & .147 & 6.881 & $* * *$ \\
\hline X1.4 & $<--$ & X1 & 1.022 & .144 & 7.092 & $* * *$ \\
\hline X1.3 & $<--$ & $\mathrm{X} 1$ & 1.064 & .149 & 7.158 & $* * *$ \\
\hline X1.2 & $<--$ & $\mathrm{X} 1$ & 1.027 & .147 & 6.985 & $* * *$ \\
\hline $\mathrm{X} 2.5$ & $<--$ & $\mathrm{X} 2$ & 1.000 & & & \\
\hline X2.4 & $<--$ & $\mathrm{X} 2$ & .928 & .087 & 10.633 & $* * *$ \\
\hline X2.3 & $<---$ & $\mathrm{X} 2$ & .819 & .098 & 8.346 & $* * *$ \\
\hline X2.2 & $<--$ & $\mathrm{X} 2$ & .875 & .115 & 7.603 & $* * *$ \\
\hline X2.1 & $<--$ & $\mathrm{X} 2$ & .540 & .094 & 5.767 & $* * *$ \\
\hline Y1.1 & $<--$ & Y1 & 1.000 & & & \\
\hline Y1.2 & $<---$ & Y1 & .782 & .172 & 4.542 & *** \\
\hline Y1.3 & $<--$ & Y1 & .915 & .125 & 7.344 & $* * *$ \\
\hline Y2.5 & $<--$ & Y2 & 2.625 & .988 & 2.656 & .008 \\
\hline Y2.4 & $<---$ & Y2 & 1.153 & .642 & 5.877 & $* * *$ \\
\hline Y2.3 & $<--$ & Y2 & .712 & .463 & 4.653 & *** \\
\hline Y2.2 & $<--$ & Y2 & 3.832 & .427 & 2.686 & .007 \\
\hline X1.6 & $<---$ & $\mathrm{X} 1$ & 1.000 & & & \\
\hline X1.1 & $<---$ & $\mathrm{X} 1$ & 1.072 & .157 & 6.838 & *** \\
\hline Y2.6 & $<--$ & Y2 & 1.000 & & & \\
\hline Y2.1 & $<--$ & Y2 & 4.062 & 1.539 & 2.640 & .008 \\
\hline
\end{tabular}

Berdasarkan hasil output pada tabel 6 , diperoleh nilai estimasi parameter dan sekaligus dilakukan pengujian hipotesisnya. Untuk melakukan pengujian hipotesis yaitu dengan melihat nilai probability (P) dan nilai Critical Ratio (CR) pada masingmasing variabel. Variabel $\mathrm{X}$ dikatakan berpengaruh terhadap varabel Y (signifikan) jika P-value bernilai kurang dari 0,05 dan nilai critical ratio $>1,96$.

a. Pengujian hipotesis 1

Hipotesis I penelitian ini adalah personal attitude bankers yang mempengaruhi kepuasan nasabah, sehingga semakin baik personal attitude bankers, semakin tinggi kepuasan nasabah. Hasil pengolahan data, dapat dilihat bahwa nilai Critical Ratio (CR) untuk hubungan antara personal attitude bankers adalah sebesar 2,781 dengan nilai probabilitas sebesar 0,005. Kedua nilai telah menunjukkan hasil yang memenuhi syarat yaitu memiliki nilai critical ratio yang lebih besar dari 1,96 dan nilai probabilitas kurang dari 0,05. Oleh karena itu, kesimpulannya bahwa hipotesis I dalam penelitian ini dapat diterima.

b. Pengujian hipotesis 2

Hipotesis II dari penelitian ini adalah bahwa personal attitude bankers berpengaruh terhadap loyalitas nasabah, sehingga semakin baik personal attitude 
bankers, maka semakin tinggi tingkat loyalitas nasabah. Berdasarkan hasil dari pengolahan data, diketahui bahwa nilai Critical Ratio (CR) antara personal attitude bankers sebesar 8,346 dan nilai probabilitas kurang dari 0,05. Kedua nilai tersebut memperlihatkan hasil yang memenuhi syarat yaitu nilai critical ratio yang lebih besar dari 1,96 dan nilai probabilitas kecil dari 0,05. Dengan demikian dapat disimpulkan bahwa hipotesis II penelitian ini dapat diterima.

c. Pengujian hipotesis 3

Hipotesis III dalam penelitian tersebut menunjukkan persepsi manfaat mempunyai pengaruh terhadap kepuasan nasabah, sehingga semakin baik persepsi manfaat, maka akan semakin tinggi terhadap kepuasan nasabah. Sesuai hasil pengolahan data, dapat diketahui bahwa nilai Critical Ratio (CR) untuk hubungan antara persepsi manfaat adalah sebesar 4,852 dengan nilai probabilitas kurang dari 0,05 . Kedua nilai tersebut memberikan hasil yang memenuhi syarat yaitu mempunyai nilai critical ratio yang lebih besar dari 1,96 dan nilai probabilitas kurang dari 0,05 . Oleh karena itu, disimpulkan bahwa hipotesis III pada penelitian ini dapat diterima.

d. Pengujian hipotesis 4

Hipotesis IV dari penelitian ini menyatakan bahwa untuk persepsi manfaat dapat mempengaruhi loyalitas nasabah, jadi semakin baik persepsi manfaat, maka akan semakin tinggi loyalitas nasabah. Berdasarkan hasil pengolahan data, dapat diketahui bahwa nilai Critical Ratio (CR) untuk hubungan antara persepsi manfaat adalah sebesar 1,967 dengan nilai probabilitas sebesar 0,049. Kedua nilai ini diatas menunjukkan bahwa nilai critical ratio yang lebih besar dari 1,96 dan nilai probabilitas kurang dari 0,05, sehingga hasil telah memenuhi syarat. Oleh karena itu, hipotesis IV pada penelitian ini disimpulkan dapat diterima.

e. Pengujian hipotesis 5

Hipotesis $\mathrm{V}$ dalam penelitian tersebut adalah tingkat kepuasan nasabah mempengaruhi loyalitas nasabah, jadi semakin tinggi dari kepuasan nasabah, maka semakin tinggi pula loyalitas nasabah. Hasil pengolahan data, dapat diketahui bahwa nilai Critical Ratio (CR) untuk hubungan antara kepuasan nasabah adalah sebesar 10,633 dengan nilai probabilitas kurang dari 0,05. Kedua nilai ini memperlihatkan hasil yang memenuhi syarat yaitu memiliki nilai critical ratio yang lebih besar dari 1,96 dan nilai probabilitas kurang dari 0,05. Oleh karena itu, dapat ditarik kesimpulan bahwa hipotesis $\mathrm{V}$ pada penelitian ini dapat diterima.

\section{Kesimpulan}

Berdasarkan hasil penelitian dapat diperoleh kesimpulan bahwa terdapat pengaruh positif antara personal attitude bankers terhadap kepuasan nasabah. Semakin baik personal attitude bankers, maka semakin tinggi kepuasan nasabah. Terdapat pengaruh positif antara personal attitude bankers terhadap loyalitas nasabah. Semakin baik personal attitude bankers pegawai, maka akan semakin tinggi loyalitas nasabah. 
Mohamad Zuaim Rusydi

Terdapat pengaruh positif antara persepsi manfaat terhadap kepuasan nasabah. Semakin baik persepsi manfaat yang dirasakan oleh nasabah, maka akan semakin tinggi kepuasan nasabah. Terdapat pengaruh positif antara persepsi manfaat terhadap loyalitas nasabah. Semakin baik persepsi manfaat, maka akan semakin tinggi loyalitas nasabah. Terdapat pengaruh positif antara kepuasan nasabah terhadap loyalitas nasabah. Semakin tinggi kepuasan nasabah, maka akan semakin tinggi pula loyalitas nasabah. 
Studi Tentang Loyalitas Nasabah Dana di PT Bank BNI Syariah Cabang Pekalongan

\section{BIBLIOGRAFI}

Al Arif, M. Nur Rianto. (2021). Dasar-dasar pemasaran bank syariah. Google Scholar

Arisena, Gede Mekse Korri. (2016). Konsep kewirausahaan pada petani melalui pendekatan Structural Equation Model (SEM). Jurnal Agribisnis Dan Agrowisata, 5(1). Google Scholar

Artanti, Yessy, \& Ningsih, Lestari. (2011). Pengaruh Penanganan Keluhan Terhadap Loyalitas Nasabah Pt. Bank Muamalat Indonesia, Tbk. Dengan Kepuasan Nasabah Sebagai Variabel Perantara (Studi pada Nasabah Bank Muamalat Cabang Surabaya). Benefit: Jurnal Manajemen Dan Bisnis, 14(2), 71-85. Google Scholar

Fahmi, Fatrika, Yozza, Hazmira, \& Hg, Izzati Rahmi. (2016). Analisis Faktor-Faktor Yang Mempengaruhi Minat Berwirausaha Mahasiswa Dengan Teknik Sem. Jurnal Matematika UNAND, 1(2), 5-12. Google Scholar

Ghozali, Imam. (2018). Aplikasi analisis multivariate dengan program IBM SPSS 25. Google Scholar

Hardi, Hardi, Wahyudi, Sugeng, \& Djastuti, Indi. (2016). Analisis Pengaruh Kualitas Layanan Dan Persepsi Manfaat Terhadap Kepuasan Nasabah Dan Pengaruhnya Terhadap Loyalitas (Studi Kasus Pada Nasabah Bank BRI Cabang Blora). Diponegoro University. Google Scholar

Husna, Yumna Maulidiya. (2021). Pengaruh Kemudahan, Keamanan, Dan Kenyamanan Online Banking Terhadap Customer Intention Pada Bank Bri Syariah Kc Semarang Dengan Lifestyle Sebagai Variabel Moderating. Google Scholar

Ishak, Muhammad Zakiy, \& Azzahroh, Evrita Putri. (2017). Pengaruh Kualitas Layanan Terhadap Loyalitas Nasabah Bank Syariah Dengan Kepuasan Nasabah Sebagai Variabel Intervening. Jebis (Jurnal Ekonomi Dan Bisnis Islam)| Journal Of Islamic Economics And Business, 3(1), 26-38. Google Scholar

Jufrizen, Jufrizen. (2016). Analisis Etika Kerja Berbasis Islam Pada Bank Syariah Di Kota Medan. Center for Open Science. Google Scholar

Koestanto, Tri Hari, \& Yuniati, Tri. (2014). Pengaruh kualitas pelayanan terhadap kepuasan pelanggan pada Bank Jatim Cabang Klampis Surabaya. Jurnal Ilmu \& Riset Manajemen, 3(10), 1-18. Google Scholar

Lee, Jeonghoon, \& Lee, Hansuk. (2013). Does satisfaction affect brand loyalty? Academy of Marketing Studies Journal, 17(2), 133. Google Scholar

Porral, Cristina Calvo, \& Lang, Mark F. (2015). Private labels: The role of manufacturer identification, brand loyalty and image on purchase intention. British Food Journal. Google Scholar 
Wakkee, Ingrid, \& Sleebos, Ed. (2015). Giving second chances: the impact of personal attitudes of bankers on their willingness to provide credit to renascent entrepreneurs. International Entrepreneurship and Management Journal, 11(4), 719-742. Google Scholar

Yusup, Febrinawati. (2018). Uji validitas dan reliabilitas instrumen penelitian kuantitatif. Tarbiyah: Jurnal Ilmiah Kependidikan, 7(1). Google Scholar

Zaelani, Achmad Udin, Husain, T., \& Budiyantara, Agus. (2020). Analisis Simulasi Sistem Penunjang Keputusan: Model Matematis Dengan Pendekatan Goodness-of Fit Berbasis Structural Equation Model. SMARTICS Journal, 6(1), 10-16. Google Scholar

Zaini, Muhammad Ardy. (2015). Konsepsi Al-Quran Dan Al-Hadits Tentang Operasional Bank Syariah. Iqtishoduna: Jurnal Ekonomi Islam, 3(1), 29-50. Google Scholar

\section{Copyright holder:}

Mohamad Zuaim Rusydi (2021)

First publication right:

Syntax Literate: Jurnal Ilmiah Indonesia

This article is licensed under:

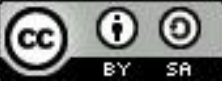

